\title{
Usulan Model Robust Newsvendor Problem Untuk Multi Produk dan Mempertimbangkan Permintaan Diskrit (Studi Kasus: Toko Roti X di Bandung)
}

\author{
Fran Setiawan*), Paulina Kus Ariningsih, dan Stefanie Widya \\ Program Studi Teknik Industri, Fakultas Teknologi Industri, Universitas Katolik Parahyangan, Jalan Ciumbuleuit No 94, \\ Bandung, 40141, Indonesia
}

DOI: 10.20961/performa.17.1.22506

\begin{abstract}
Abstrak
Jumlah usaha yang tidak mempunyai bangunan khusus untuk berjualan di Indonesia adalah sebanyak 18,9 juta usaha. Salah satu usaha yang tidak mempunyai bangunan khusus untuk berjualan adalah pedagang keliling. Jumlah pedagang keliling yang cukup banyak membuat produktivitas dan daya saing usaha perlu ditingkatkan. Permasalahan yang dihadapi oleh pedagang keliling adalah menentukan jenis dan jumlah dari tiap-tiap jenis barang yang harus dibawa setiap harinya. Jika barang yang dibawa terlalu banyak dapat menimbulkan overstock yang mengakibatkan barang sisa tidak dapat dijual pada periode penjualan berikutnya. Jika barang yang dibawa terlalu sedikit dapat menimbulkan kekurangan sehingga menimbulkan shortage yang dapat mengakibatkan hilangnya kesempatan melakukan penjualan ataupun kesempatan mendapatkan profit untuk suatu jenis barang tertentu di wilayah tertentu. Pada penelitian ini permasalahan diatas akan dimodelkan sebagai permasalahan robust newsvendor problem untuk multi produk dan mempertimbangkan permintaan diskrit. Model ini menentukan jumlah optimal yang harus dibawa oleh pedagang keliling setiap harinya untuk setiap jenis produk yang dapat memaksimalkan ekspektasi profit dari kemungkinan terburuk yang dapat terjadi ketika hanya diketahui beberapa informasi dari distribusi permintaan. Setelah mengembangkan model, kemudian dibuat program penyelesaian model dengan menggunakan software Octave. Studi kasus yang digunakan adalah pedagang roti keliling sebuah toko roti di Bandung. Hasil dari implementasi model yang sudah dikembangkan dapat meningkatkan rata-rata ekspektasi profit yang didapatkan oleh pedagang keliling pertama dan pedagang keliling kedua berturut-turut sebesar $126.77 \%$ dan $268.3987 \%$ dari rata-rata profit yang didapatkan oleh kedua pedagang keliling saat ini.
\end{abstract}

Kata kunci: pedagang keliling, robust, multiproduct newsvendor problem, discrete demand

\begin{abstract}
In Indonesia, the number of businesses that do not have a special building is 18.9 million business. One business that does not have a special building is a peddler. A considerable number of peddlers make the productivity and competitiveness of peddlers need to be improved. The problem faced by the peddler is to determine the type and the amount of each type of goods that must be brought each day. If the goods brought too many can cause overstocks that result in remaining goods can not be sold in the next sales period. If the goods brought too few can cause shortages that can lead to loss of opportunities to make sales or profit for a particular type of goods in a particular region. In this research, this problem will be modeled as a robust multi-product newsvendor problem with discrete demand. This model determines the optimal number that everyday peddler must bring for each type of product that maximizes the expected profit from the worst possibility that can occur when only some information from the demand distribution is known. After developing the model, then made a model completion program using Octave software. The case study used in this research is peddler of a bakery shop in Bandung. The results of the implementation of the developed model can increase the average of expected profit obtained by the first and second peddlers by $126.77 \%$ and $268.3987 \%$ respectively of the average current profit earned by the both peddlers.
\end{abstract}

Keywords: peddler, robust, multiproduct newsvendor problem, discrete demand

\section{Pendahuluan}

Badan Pusat Statistik (BPS) telah melakukan sensus ekonomi pada pertengahan tahun 2016 untuk mengetahui gambaran tentang struktur ekonomi suatu negara menurut wilayah, lapangan usaha dan skala usaha. Dari sensus yang diadakan setiap 10 tahun sekali ini, tercatat jumlah usaha non-pertanian mencapai 26.7 juta usaha. Angka ini meningkat 17,6 persen atau sebanyak 4 juta jika dibandingkan jumlah usaha hasil sensus ekonomi tahun 2006 sebanyak 22.7 juta usaha. Dari 26.7 juta usaha non-pertanian, tercatat sebanyak 7,8 juta usaha menempati bangunan khusus usaha, sementara 18,9 juta usaha tidak menempati bangunan khusus usaha.

Berdasarkan data diatas dapat dilihat bahwa di Indonesia banyak terdapat jenis usaha yang tidak menempati bangunan khusus usaha seperti pedagang keliling, usaha didalam rumah tempat tinggal, usaha kaki lima dan

\footnotetext{
${ }^{*}$ Korespondensi : fransetiawan@ unpar.ac.id
} 
sebagainya. Oleh karena itu, produktivitas dan daya saing usaha perlu ditingkatkan karena banyaknya jumlah pesaing pada jenis usaha tersebut. Pedagang keliling adalah pedagang yang menjajakan barang yang dijualnya menggunakan gerobak atau box dan keliling disuatu wilayah pasar tertentu. Contoh pedagang keliling di Indonesia adalah pedagang roti keliling, pedagang sayur keliling, pedagang es krim keliling dll.

Barang yang dibawa dan dijajakan oleh pedagang keliling biasanya terdiri dari berbagai jenis produk, misalnya saja pada pedagang roti keliling dimana produk yang dijual terdiri dari roti cokelat, roti keju, roti tawar, roti strawberry, roti nanas, roti sarikaya dll. Masalah yang umumnya dihadapi oleh penjual keliling adalah terjadinya kelebihan suatu jenis barang tertentu sehingga menimbulkan overstock ataupun kekurangan sehingga menimbulkan shortage yang dapat mengakibatkan hilangnya kesempatan melakukan penjualan ataupun kesempatan mendapatkan profit untuk suatu jenis barang tertentu di wilayah tertentu. Misalnya saja pedagang keliling A membawa 10 buah roti cokelat ke wilayah pemasaran X dan permintaan roti cokelat diwilayah X sebanyak 12 buah. Hal ini berarti pedagang keliling A kehilangan kesempatan untuk menjual dan mendapatkan profit 2 buah roti cokelat sementara mungkin pedagang keliling B yang menjual ke wilayah pemasaran Y pada akhir masa keliling masih terdapat kelebihan persediaan roti cokelat yang tidak laku terjual.

Permasalahan diatas dapat dimodelkan sebagai permasalahan newsvendor problem untuk multi produk. Menurut Choi (2012), permasalahan tukang loper koran (newsvendor problem) merupakan permasalahan dasar pemodelan persediaan yang bersifat stokastik. Permasalahan ini sudah banyak diteliti sejak abad ke-18 dan telah diaplikasikan secara luas dalam permasalahan rantai pasok untuk produk yang bersifat umur pendek (perishable). Contoh produk yang memiliki umur pendek adalah koran yang tidak dapat dijual lagi pada keesokan harinya, kue atau roti yang di produksi pada hari ini yang akan tidak enak lagi untuk keesokan harinya, pohon natal yang hanya akan dibeli orang pada musim natal, produk fashion yang hanya dapat dijual pada musim jualnya saja, dll. Mulai dari tahun 1950, permasalahan ini banyak diteliti dalam ranah penelitian riset operasi dan model banyak dikembangkan untuk disesuaikan dengan kasus nyata. Model paling sederhana dari permasalahan ini adalah bagaimana tukang loper koran memutuskan akan memesan sejumlah berapa koran kepada agen koran dimana permintaan koran belum diketahui secara pasti. Koran yang tidak terjual pada hari itu akan habis masa jualnya. Tukang loper koran kemudian menentukan jumlah pesanan koran yang optimal yang dapat memaksimalkan profit atau meminimasi biaya yang mungkin terjadi.

Multi-product newsvendor problem adalah permasalahan dimana pada awal suatu periode masa jual, pedagang akan memutuskan berapa jumlah optimal dari masing-masing barang yang akan dibeli atau dibawa dalam suatu periode masa jual untuk memaksimalkan ekspektasi profit secara keseluruhan (Turken et al in Choi, 2012). Untuk setiap jenis produk permintaan diasumsikan permintaan bersifat stokastik berupa variabel acak dengan probability density function $f_{i}$ dan cumulative distribution function $F_{i}$. Beberapa penelitian mengenai muti-product newsvendor problem mengarah kepada adanya batasan, misalnya batasan kapasitas atau kapasitas budget yang dimiliki. (Hadley dan Whitin, 1963; Nahmias dan Schmidt, 1984; Lau and Lau, 1996; Abdel-Malek et al, 2004; dll).

Tradisional newsvendor problem mengasumsikan bahwa parameter dari distribusi probabilitas permintaan sudah diketahui. Pemodelan robust dipilih karena dalam prakteknya sering kali sulit bagi pembuat keputusan untuk dapat mengetahui karakteristik dari distribusi permintaan sehingga akhir-akhir ini beberapa peneliti menggunakan model robust untuk mengatasi permasalahan kurangnya informasi mengenai distribusi permintaan. Pemodelan robust memungkinkan kita untuk menentukan jumlah pesanan optimal untuk kejadian terburuk yang mungkin terjadi (worst case) ketika hanya tersedia beberapa informasi tentang distribusi permintaan ( $\mathrm{Yu}$ et al, 2004). Robust newsvendor problem pertama kali diteliti oleh Scarf (1958), penelitian ini menghasilkan bentuk close-form untuk menentukan jumlah pesanan optimal yang memaksimumkan ekspektasi profit berdasarkan kemungkinan terburuk dari distribusi permintaan dengan hanya diketahui rata-rata dan variansi. Gallego dan Moon (1993), membuktikan rumusan yang dihasilkan oleh Scarf untuk newsvendor problem ketika hanya diketahui rata-rata dan variansi dari permintaan dan mengembangkan rumusan tersebut kedalam tiga kasus, pertama dimana ada kesempatan pembelian kedua, ada biaya tetap ketika melakukan pembelian dan ada beberapa jenis produk.

Beberapa penelitian mengenai robust newsvendor problem yang ada saat ini mengasumsikan bahwa permintaan merupakan variabel acak kontinu, sedangkan permintaan untuk banyak produk bersifat diskrit. Contohnya permintaan konsumen terhadap suatu roti bersifat diskrit, permintaan untuk roti coklat dalam 1 hari sebanyak 10 buah, roti stroberi sebanyak 8 buah, dll. Penelitian mengenai permasalahan robust newsvendor problem dengan mempertimbangkan permintaan diskrit baru dilakukan oleh Yu et al (2014). Yu et al berhasil menghasilkan suatu model untuk menentukan jumlah pesanan optimal untuk permasalahan robust newsvendor problem with discrete demand, dimana pembuat keputusan memaksimalkan profit dari kemungkinan terburuk.

Berdasarkan permasalahan yang dijelaskan diatas, maka penelitian ini mencoba menyelesaikan permasalahan diatas untuk meningkatkan produktivitas dan daya saing pedagang keliling. Pada penelitian sebelumnya yang dilakukan oleh Yu et al (2014) belum dilakukan implementasi pada kasus nyata tetapi baru hanya sebatas pada kasus hipotetik pada penelitian yang dilakukan oleh Scarf (1958) sehingga pada penelitian ini akan dilakukan implementasi pada kasus nyata. Studi kasus pada penelitian ini adalah pada pedagang roti 
keliling sebuah toko roti di Bandung. Penelitian ini nantinya akan dibuat model matematis untuk membantu pedagang keliling memutuskan berapa banyak barang yang akan dibawa untuk setiap jenisnya sehingga dapat memaksimalkan perkiraan (expected) profit. Model yang dibangun merupakan extended model dari newsvendor problem yaitu robust newsvendor problem untuk multi produk dan mempertimbangkan permintaan diskrit.

\section{Metode Penelitian}

Bagian ini berisikan penjelasan tentang bagaimana penelitian ini dilakukan (metodologi penelitian). Penelitian ini dimulai dengan identifikasi masalah, perumusan masalah, studi literatur, penentuan batasan dan asumsi penelitian, pengembangan model, validasi model, pembuatan algoritma penyelesaian model, pembuatan program penyelesaian model, verifikasi program, pengumpulan data, implementasi model, hasil dan pembahasan, dan penarikan kesimpulan. Penjelasan masing-masing tahapan penelitian adalah sebagai berikut:

a. Identifikasi masalah

Pada tahap ini peneliti mengidentifikasi permasalahan yang dihadapi oleh pedagang keliling yang membawa beberapa jenis barang perishable dengan tidak diketahui parameter dari distribusi probabilitas permintaan. Permintaan produk berupa diskrit. Permasalahan yang dihadapi adalah jumlah barang dari tiap jenis barang yang dibawa atau dibeli diawal periode bisa terlalu banyak sehingga menimbulkan kerugian apabila tidak terjual karena tidak dapat dijual lagi pada periode penjualan berikutnya dan terlalu sedikit sehingga pedagang kehilangan kesempatan untuk mendapatkan profit

b. Perumusan masalah

Pada tahap ini peneliti merumuskan masalah dari penelitian ini yaitu berapa jumlah yang harus dibawa dari masing-masing jenis barang untuk memaksimalkan profit.

c. Studi literatur

Pada tahap ini peneliti melakukan studi literatur mengenai newsvendor problem, muti-product newsvendor problem, robust newsvendor problem dan robust multi-product newsvendor problem untuk melihat state of the art dari newsvendor problem yaitu belum adanya penelitian membahas kasus multi-product newsvendor problem with discrete demand dan menemukan kontribusi dari penelitian ini yaitu mengembangkan model robust newsvendor problem untuk multi produk dan mempertimbangkan permintaan diskrit.

d. Penentuan batasan dan asumsi penelitian

Pada tahap ini peneliti menentukan batasan dan asumsi penelitian yaitu tidak ada batasan kapasitas dan batasan budget yang dimiliki oleh pedagang.

e. Pengembangan model

Pada tahap ini peneliti mengembangkan model robust newsvendor problem untuk multi produk dan mempertimbangkan permintaan diskrit. dengan mengembangkan model robust newsvendor problem with discrete demand yang dibuat oleh Yu et al (2014).

f. Validasi model

Pada tahap ini model yang sudah dikembangkan kemudian dilakukan validasi apakah model yang sudah dikembangkan sudah sesuai dengan permasalahan robust newsvendor problem untuk multi produk dan mempertimbangkan permintaan diskrit.

g. Pembuatan algoritma penyelesaian model

Pada tahap ini peneliti membuat algoritma penyelesaian model untuk menyelesaikan model tersebut secara enumerasi.

h. Pembuatan program penyelesaian model

Pada tahap ini peneliti membuat program penyelesaian model secara enumerasi berdasarkan algoritma penyelesaian model yang sudah dibuat sebelumnya

i. Verifikasi program

Pada tahap ini peneliti melakukan verifikasi program untuk melihat apakah program yang dibuat sudah benar dengan membandingkan hasil dari program dengan hasil dari penelitian dari Yu et al (2014) dengan membuat permasalahan pada peneltian Yu et al menjadi permasalahan multi-product.

j. Pengumpulan data

Pada tahap ini dilakukan pengumpulan data pada pedagang keliling sebuah toko roti di Bandung. Penelitian ini menggunakan studi kasus pada suatu toko roti di Bandung, Data yang dikumpulkan adalah data penjualan kedua pedagang keliling toko roti tersebut pada bulan Oktober 2017 hingga Maret 2018, data harga jual tiap jenis roti, biaya produksi tiap jenis roti, dan jumlah roti yang tersisa dari kedua pedagang keliling untuk setiap jenis roti.

k. Implementasi model 
Pada tahap ini akan dilakukan implementasi model pada kasus nyata yaitu pedangang keliling sebuah toko roti di Bandung. Model akan diimplementasikan untuk menentukan jenis dan jumlah roti yang harus dibawa setiap harinya oleh pedagang keliling agar profit yang didapat maksimal.

1. Hasil dan pembahasan

Pada tahap ini peneliti akan melaporkan hasil implementasi model pada kasus nyata dan kemudian melakukan analisis terhadap hasil yang diperoleh

m. Penarikan kesimpulan

Pada tahap ini peneliti menarik kesimpulan mengenai hasil pemecahan masalah yang dihadapi oleh pedagang keliling.

\section{Hasil dan Pembahasan}

\subsection{Pengembangan Model, Asumsi dan Notasi}

Model yang dikembangkan adalah robust newsvendor problem untuk multi produk dan mempertimbangkan permintaan diskrit. Model ini merupakan pengembangan dari model robust newsvendor problem with discrete demand yang dimodelkan oleh Yu et al (2014). Permasalahan robust newsvendor problem untuk multi produk dan mempertimbangkan permintaan diskrit dalam penelitian ini adalah seorang pedagang roti keliling harus memutuskan jenis dan jumlah roti yang harus ia bawa setiap harinya agar profit yang didapatkannya maksimal. Permasalahan yang dihadapi adalah jika terlalu banyak membawa satu jenis roti maka terdapat roti sisa yang tidak dapat dijual kembali dikemudian hari sedangkan jika membawa terlalu sedikit, pedagang kehilangan kesempatan untuk mendapatkan keuntungan. Pada penelitian ini diasumsikan pedagang keliling hanya mengetahui beberapa titik permintaan diskrit dari tiap jenis roti, rata-rata dari titik-titik permintaan diskrit, variansi dari titik-titik permintaan diskrit dan tidak mengetahui probabilitas dari masingmasing titik permintaan diskrit tersebut. Distribusi probabilitas diskrit dari permintaan tidak diketahui.

Secara matematis, permasalahan ini digambarkan sebagai berikut, diasumsikan bahwa $\mathrm{F}_{1}$ adalah distribusi probabilitas diskrit yang tidak diketahui dari produk $l$ dengan hanya diketahui beberapa titik permintaan untuk produk $l$ yaitu $X_{l 1}, X_{l 2}, \ldots, X_{l n}$ dan $F_{l} \in \Gamma\left(\mu_{l}, \sigma_{l}^{2}\right) . \mu_{l}$ adalah rata-rata dari permintaan produk $l$ dan $\sigma_{l}^{2}$ adalah variansinya. Probabilitas masing-masing titik permintaan $P_{l 1}, P_{l 2}, \ldots, P_{l n}$ tidak diketahui. Pengambil keputusan yang dalam kasus ini adalah pedagang keliling akan memutuskan berapa jumlah dari masing-masing jenis roti yang akan dibawa $\left(q_{l}\right) . D_{l}$ adalah permintaan stokastik dari produk $l$. Pedagang keliling membawa tiap jenis roti yang biaya produksinya sebesar $c_{l}$ dan dijual dengan harga jual $p_{l}$. Ketika $q_{l}>D_{l}$ setiap jenis dan jumlah roti yang tersisa diakhir masa jual akan dijual dengan harga $s_{l}$ Model robust ini akan diselesaikan dalam dua tahap seperti pada model robust newsvendor model with continuous demand oleh Scarf (1958) didalam Yu et al (2014). Model matematis untuk robust newsvendor problem untuk multi produk dan mempertimbangkan permintaan diskrit adalah sebagai berikut:

$$
\max _{q_{l} F \in \Gamma\left(\mu_{l}, \sigma_{l}^{2}\right)} \sum_{l=1}^{m} E\left[\pi\left(q_{l}, D_{l}\right)\right]
$$

Pertama, selesaikan terlebih dahulu masalah pertama (inner problem) (M1) dari model robust. Model dari permasalahan pertama adalah sebagai berikut: subject to

$$
\min _{p_{\text {in }}} E\left[\pi\left(q_{l}, D_{l}\right)\right]=\sum_{l=1}^{m}\left(p_{l}-s_{l}\right)\left(\sum_{k=1}^{n} \min \left(q_{l}, X_{l k}\right) P_{l k}-\frac{c_{l}-s_{l}}{p_{l}-s_{l}} q_{l}\right)
$$

$$
\begin{array}{ll}
P_{l 1}, \ldots, P_{l n} \geq 0 & \forall l \in m \\
\sum_{k=1}^{n} P_{l k}=1 & \forall l \in m \\
\sum_{k=1}^{n} x_{l k} P_{l k}=\mu_{l} & \forall l \in m \\
\sum_{k=1}^{n} x_{l k}^{2} P_{l k}=\mu_{l}^{2}+\sigma_{l}^{2} & \forall l \in m
\end{array}
$$

Model primal diatas kemudian akan diubah menjadi model dualnya untuk menganalisis masalah pertama (M1). Berikut ini adalah model dual dari model primal M1

subject to

$$
\max \sum_{l=1}^{m} y_{1}+\mu_{l} y_{2}+\left(\mu_{l}^{2}+\sigma_{l}^{2}\right) y_{3}
$$

$$
\begin{gathered}
\sum_{l=1}^{m} y_{1}+x_{l k} y_{2}+x_{l k}^{2} y_{3} \leq \sum_{l=1}^{m}\left(p_{l}-s_{l}\right)\left(\min \left(q_{l}, x_{l k}\right)-\frac{c_{l}-s_{l}}{p_{l}-s_{l}} q_{l}\right) \forall k=1, \ldots, n \\
y_{1}, y_{2}, y_{3} U R S
\end{gathered}
$$

Berdasarkan analisa pada model dual diatas yang ekuivalen dengan teori dasar pemrograman linear yang menyatakan bahwa ada solusi optimal sedemikian rupa sehingga jumlah variabel bukan nol tidak lebih dari jumlah kendala. Oleh karena itu untuk model pemrograman primalnya, jumlah variabel bukan nol $P_{k}^{*}$ tidak lebih dari tiga. Hal ini menunjukkan bahwa probability mass terkonsentrasi pada tiga titik. Oleh karena itu kita cukup 
hanya dengan menganalisis distribusi tiga titik. Dari distribusi tiga titik ini kemudian kita akan mendapatkan bentuk close-form dari $\pi\left(q_{l}\right)$. Setelah mendapatkan bentuk close-form dari $\pi\left(q_{l}\right)$ kemudian kita menyelesaikan masalah kedua (outer problem) (M2) dari robust model yaitu

$$
\max _{q_{l}} \pi\left(q_{l}\right)
$$

Fungsi $\pi\left(q_{l}\right)$ merupakan fungsi piecewise linear function dan disitu terdapat jumlah order robust optimal $q_{l}^{*}$ yang memaksimalkan $\pi\left(q_{l}\right)$. Kita tidak dapat memperoleh rumusan dari $q_{l}^{*}$ karena nilainya ditentukan oleh nilai titik permintaan. Kita dapat membuat program enumerasi untuk mendapatkan nilai $q_{l}^{*}$. Algoritma program enumerasi untuk menyelesaikan model diatas dapat dilihat pada bagian 3.2.

\subsection{Algoritma penyelesaian}

Berdasarkan analisis pada model dual permasalahan pertama (M1) pada model robust, langkah selanjutnya adalah membuat algoritma penyelesaian untuk model robust newsvendor problem untuk multi produk dan mempertimbangkan permintaan diskrit. Berdasarkan analisis pada model dual pada penelitian yang dilakukan oleh Yu et al (2014), hanya diperlukan untuk mempertimbangkan tiga titik permintaan yang berdekatan untuk masing-masing produk $l$. Untuk memenuhi dual feasibility, paling tidak dua dari tiga titik permintaan harus berdekatan. Langkah-langkah penyelesaian adalah sebagai berikut:

1. Untuk setiap produk $l$, pilih secara sembarang tiga titik permintaan $x_{l i}, x_{l i+1}, x_{l j}$ dimana $x_{l i}$ dan $x_{l i+1}$ berdekatan. Tentukan apakah distribusi tiga titik ini memenuhi primal feasibility atau tidak. Jika tidak maka cari atau ambil tiga titik lainnya. Jika memenuhi primal feasibility maka lanjut ke tahap 2.

2. Cari interval nilai fixed q yang layak untuk memastikan terpenuhinya dual feasibility

3. Dapatkan bentuk close-form dari $\pi(\mathrm{q})$ pada interval dual feasible dari nilai fixed $\mathrm{q}$

4. Lanjutkan untuk produk berikutnya

Asumsikan probabilitas untuk ketiga titik permintaan adalah sebagai berikut

$$
\begin{aligned}
& P_{l j}^{*}=\frac{\sigma_{l}^{2}+\left(\mu_{l}-x_{l i}\right)\left(\mu_{l}-x_{l i+1}\right)}{\left(x_{l j}-x_{l i}\right)\left(x_{l j}-x_{l i+1}\right)} \\
& P_{l i}^{*}=\frac{\sigma_{l}^{2}+\left(\mu_{l}-x_{l j}\right)\left(\mu_{l}-x_{l i+1}\right)}{\left(x_{l i}-x_{l j}\right)\left(x_{l i}-x_{l i+1}\right)} \\
& P_{l i+1}^{*}=\frac{\sigma_{l}^{2}+\left(\mu_{l}-x_{l j}\right)\left(\mu_{l}-x_{l i}\right)}{\left(x_{l i+1}-x_{l j}\right)\left(x_{l i+1}-x_{l i}\right)} \\
& P_{l k}^{*}=0, k=1,2, \ldots, n, k \neq j, i, i+1
\end{aligned}
$$

Kemudian dibagi $x_{l j}<x_{l i}$ dan $x_{j}>x_{l i+1}$ ke dalam kasus 1 dan kasus 2.

Kasus 1: untuk sembarang $2 \leq \mathrm{i} \leq \mathrm{n}-1,1 \leq \mathrm{j} \leq \mathrm{i}-1$ dan fixed q jika

$$
\begin{aligned}
& \max \left\{\left(x_{l i}-\mu_{l}\right)\left(\mu_{l}-x_{l j}\right),\left(x_{l i+1}-\mu_{l}\right)\left(\mu_{l}-x_{l i}\right)\right\} \leq \sigma_{l}^{2} \leq\left(x_{l i+1}-\mu_{l}\right)\left(\mu_{l}-x_{l j}\right) \\
& \text { dan } \\
& \quad \frac{x_{l i} x_{l i+1}-x_{l j-1} x_{l j}}{\left(x_{l i}+x_{l i+1}\right)-\left(x_{l j-1}+x_{l j}\right)}<q_{l} \leq \frac{x_{l i} x_{l i+1}-x_{l j} x_{j+1}}{\left(x_{l i}+x_{l i+1}\right)-\left(x_{l j}+x_{l j+1}\right)}, \text { for } 2 \leq \mathrm{j} \leq \mathrm{i}-1 \\
& \quad x_{j}<q_{l} \leq \frac{x_{l i} x_{l i+1}-x_{l j} x_{l j+1}}{\left(x_{l i}+x_{l i+1}\right)-\left(x_{l j}+x_{l j+1}\right)}, \text { for } \mathrm{j}=1 \\
& \text { Maka } \pi\left(q_{l}\right)=\left(p_{i}-s_{i}\right) x_{l j} P_{l j}^{*}+\left[\left(p_{i}-s_{i}\right)\left(1-P_{l j}^{*}\right)-\left(c_{i}-s_{i}\right) q_{i}\right]
\end{aligned}
$$

Kasus 2: untuk sembarang $1 \leq \mathrm{i} \leq \mathrm{n}-2, \mathrm{i}+2 \leq \mathrm{j} \leq \mathrm{n}$ dan fixed q jika

$$
\begin{aligned}
& \quad \max \left\{\left(x_{l i+1}-\mu_{l}\right)\left(\mu_{l}-x_{l i}\right),\left(x_{l j}-\mu_{l}\right)\left(\mu_{l}-x_{l i+1}\right)\right\} \leq \sigma_{l}^{2} \leq\left(x_{l j}-\mu_{l}\right)\left(\mu_{l}-x_{l i}\right) \\
& \text { dan } \\
& \quad \frac{x_{l j-1} x_{l j}-x_{l i} x_{l i+1}}{\left(x_{l j-1}+x_{l j}\right)-\left(x_{l i}+x_{l i+1}\right)}<q_{l} \leq \frac{x_{l j} x_{l j+1}-x_{l i} x_{i+1}}{\left(x_{l j}+x_{l j+1}\right)-\left(x_{l i}+x_{l i+1}\right)}, \text { for } \mathrm{i}+2 \leq \mathrm{j} \leq \mathrm{n}-1 \\
& \quad \frac{x_{l j-1} x_{l j}-x_{l i} x_{l i+1}}{\left(x_{l j-1}+x_{l j}\right)-\left(x_{l i}+x_{l i+1}\right)} \leq q_{l}<x_{j}, \text { for } \mathrm{j}=\mathrm{n} \\
& \text { Maka } \pi\left(q_{l}\right)=\left(p_{i}-s_{i}\right)\left(x_{l i} P_{l i}^{*}+x_{i+1} P_{l i+1}^{*}\right)+\left[\left(p_{i}-s_{i}\right) P_{l j}^{*}-\left(c_{i}-s_{i}\right) q_{i}\right]
\end{aligned}
$$

Setelah didapatkan nilai $\pi\left(q_{l}\right)$ selanjutnya adalah menyelesaikan masalah kedua (M2) dari model robust. $\pi\left(q_{l}\right)$ merupakan piecewise linear function dan terdapat solusi robust optimal untuk jumlah order $q_{l}^{*}$ yang memaksimalkan $\pi\left(q_{l}\right)$. Nilai jumlah order ini ditentukan oleh nilai dari titik permintaan. Pembaca yang tertarik untuk menetahui pembuktian rumus dan langkah-langkah diatas dapat melihat pada penelitian yang dilakukan oleh Yu et al (2014). Pada penelitian ini algoritma diatas akan dibuat programnya menggunakan software Octave untuk menemukan nilai $q_{l}^{*}$.

\subsection{Validasi model dan verifikasi program penyelesaian model}

Model robust newsvendor problem untuk multi produk dan mempertimbangkan permintaan diskrit yang sudah dikembangkan beserta program penyelesaiannya akan dilakukan validasi dan verifikasi untuk mengetahui 
apakah model yang telah dikembangkan sudah benar yaitu dapat memberikan solusi permasalahan robust newsvendor problem untuk multi produk dan mempertimbangkan permintaan diskrit. Validasi dan verifikasi dilakukan dengan menggunakan data yang dibuat oleh Scarf (1958) pada penelitian Yu et al (2014). Data yang digunakan untuk validasi dan verifikasi tersebut dapat dilihat pada tabel 1 dibawah ini

Tabel 1. Data yang digunakan untuk validasi dan verifikasi

\begin{tabular}{|c|c|c|c|c|c|c|c|c|c|c|}
\hline $\mathrm{p}$ & c & $\mathrm{s}$ & $\mu$ & $\sigma$ & $\mathrm{X}_{1}$ & $\mathrm{X}_{2}$ & $\mathrm{X}_{3}$ & $\mathrm{X}_{4}$ & $\mathrm{X}_{5}$ & $\mathrm{q}^{*}$ \\
\hline \multirow{3}{*}{50} & \multirow{3}{*}{35} & \multirow{3}{*}{25} & \multirow{3}{*}{1000} & \multirow{3}{*}{500} & 100 & 500 & 1100 & 1500 & 2000 & 1288.7 \\
\hline & & & & & 100 & 300 & 500 & 1000 & 2000 & 999.6 \\
\hline & & & & & 100 & 200 & 1300 & 1800 & 2000 & 1300.1 \\
\hline
\end{tabular}

Tabel 1 diatas memberikan ada sebuah produk dengan 3 pola permintaan yang masing-masing memiliki 5 titik permintaan (dinotasikan sebagai $\mathrm{X}_{1}, \mathrm{X}_{2}, \mathrm{X}_{3}, \mathrm{X}_{4}$ dan $\mathrm{X}_{5}$ ). Pola permintaan pertama memiliki titik permintaan 100, 500, 1100, 1500, 2000. Pola permintaan kedua memiliki titik permintaan 100, 300, 500, 1000, 2000. Pola permintaan ketiga memiliki titik permintaan 100, 200, 1300, 1800, 2000. Produk tersebut memiliki harga jual $\mathrm{p}=50$, harga beli $\mathrm{c}=35$ dan apabila tidak laku akan dijual dengan harga $\mathrm{s}=25$. Rata-rata permintaan $(\mu)$ sebesar 1000 dan standar deviasi permintaan $(\sigma)$ 500. Kolom q* menunjukkan jumlah order robust optimal hasil penelitian Yu et al (2014) untuk produk tersebut.

Dalam penelitian ini, untuk keperluan validasi dan verifikasi, data tersebut nantinya akan dianggap sebagai data dengan 3 jenis produk dengan pola permintaan pertama dianggap sebagai pola permintaan produk pertama, pola permintaan kedua dianggap sebagai pola permintaan produk kedua dan pola permintaan ketiga dianggap sebagai pola permintaan produk ketiga karena penelitian ini akan menyelesaikan permasalahan multi produk. Data tersebut kemudian diselesaikan dengan menggunakan program penyelesaian model yang dibuat dengan menggunakan software Octave. Berikut adalah hasil penyelesaian kasus diatas oleh software Octave

v_Optimum $=$

$9.4717 e+0031.0831 e+004 \quad 1.1843 e+004$

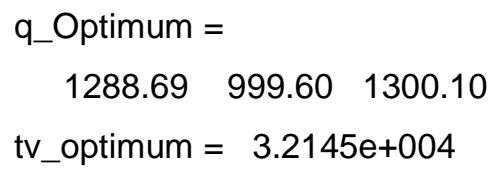

Dari hasil penyelesaian kasus diatas oleh software octave dapat dilihat bahwa hasil dari software Octave untuk multiproduct sama dengan hasil pada penelitian yang dilakukan oleh Yu et al (2014) untuk single product dan nilai $q_{l}^{*}$ masih berada dalam rentang nilai titik permintaan. Hal ini menunjukkan bahwa model robust newsvendor problem untuk multi produk dan mempertimbangkan permintaan diskrit yang telah dikembangkan sudah valid dan program penyelesaian model sudah terverifikasi sehingga dapat digunakan untuk menyelesaikan kasus nyata permasalahan robust newsvendor problem untuk multi produk dan mempertimbangkan permintaan diskrit.

\subsection{Studi Kasus}

Model dan program penyelesaian yang sudah valid dan terverifikasi kemudian akan diimplementasikan pada kasus nyata permasalahan robust newsvendor problem untuk multi produk dan mempertimbangkan permintaan diskrit. Kasus nyata pada penelitian ini diambil dari sebuah toko roti di Bandung dengan menentukan jumlah dan jenis roti yang harus dibawa oleh kedua pedagang keliling toko roti tersebut setiap harinya. Toko roti ini memiliki 2 pedagang keliling yang setiap hari berjualan. Data yang digunakan adalah data penjualan roti dan data sisa roti setiap harinya pada bulan Juli 2017 sampai dengan Januari 2018. Sebelum dilakukan pengolahan data dengan menggunakan program penyelesaian, data yang telah dikumpulkan dari roti $\mathrm{X}$ diamati terlebih dahulu untuk menentukan apakah data dapat langsung dilakukan pengolahan data. Dari pengamatan yang dilakukan, ditemukan bahwa terdapat perbedaan jenis roti yang dibawa oleh pedagang keliling setiap harinya. Pada hari Senin, Kamis dan Sabtu kedua pedagang keliling hanya membawa 20 jenis roti. Pada hari Selasa dan Rabu kedua pedangang keliling membawa 21 jenis roti. Pada hari Jumat kedua pedagang keliling membawa 19 jenis roti. Untuk pengamatan lebih lanjut, dilakukan uji Kruskal-Wallis untuk melihat apakah terdapat perbedaan hasil penjualan pada hari Senin, Kamis, Sabtu dan pada hari Selasa, Rabu untuk masing-masing pedagang keliling. Berikut adalah hipotesis awal dan hipotesis tandingan pada uji Kruskal-Wallis yang dilakukan.

$\mathrm{H}_{0}$ : tidak terdapat perbedaan penjualan antar hari

$\mathrm{H}_{1}$ : terdapat perbedaan penjualan minimal antar 2 hari

Nilai alpha $(\alpha)$ yang digunakan adalah 0.05

Uji Kruskal-Wallis dilakukan dengan menggunakan software Minitab. Hasil dari uji Kruskal-Wallis untuk hari Senin, Kamis dan Sabtu untuk pedagang pertama dapat dilihat pada Gambar 1 dibawah ini 


\section{Kruskal-Wallis Test: Jumlah Ahmad versus Hari Ahmad}

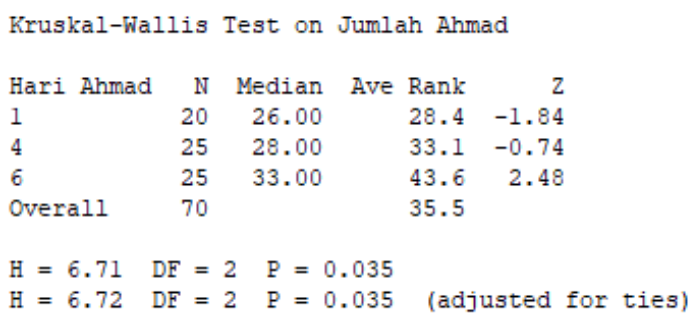

Gambar 1. Hasil uji Kruskal-Wallis hari Senin, Kamis dan Sabtu pedagang pertama

Dapat dilihat pada gambar 1 diatas bahwa P-Value hasil uji Kruskal-Wallis adalah sebesar 0.035. P-Value yang diperoleh kurang dari nilai $\alpha$ sehingga dapat disimpulkan bahwa terdapat perbedaan jumlah penjualan pada hari Senin, Kamis, dan Sabtu. Pengujian juga dilakukan untuk pedagang kedua dan untuk penjualan pada hari Rabu dan Selasa. Rekapitulasi hasil uji Kruskal-Wallis dapat dilihat pada tabel 2 dibawah ini

Tabel 2. Rekapitulasi hasil uji Kruskal-Wallis untuk kedua pedangang keliling

\begin{tabular}{|c|c|c|c|c|}
\hline \multirow{2}{*}{ Hari } & \multicolumn{3}{|c|}{ Pedagang } \\
\cline { 2 - 5 } & \multicolumn{2}{|c|}{ Pertama } & Kedua \\
\cline { 2 - 5 } & P-Value & Kesimpulan & P-Value & Kesimpulan \\
\hline Senin, Kamis, Jumat & 0.035 & Tolak $\mathrm{H}_{0}$ & 0.208 & Tidak menolak $\mathrm{H}_{0}$ \\
\hline Selasa, Rabu & 0.656 & Tidak menolak $\mathrm{H}_{0}$ & 0.519 & Tidak menolak $\mathrm{H}_{0}$ \\
\hline
\end{tabular}

Tabel 2 menunjukkan bahwa kesimpulan dari uji Kruskal-Wallis hari Senin, Kamis, dan Sabtu pada pedagang pertama adalah tolak $\mathrm{H}_{0}$ yang berarti terdapat perbedaan jumlah penjualan pada hari Senin, Kamis, dan Sabtu sehingga keputusan untuk ketiga hari tersebut tidak bisa disamakan. Kesimpulan untuk uji KruskalWallis hari Senin, Kamis, dan Sabtu pada pedagang kedua dan hari Selasa dan Rabu pada kedua pedagang adalah tidak menolak $\mathrm{H}_{0}$ yang berarti tidak terdapat perbedaan penjualan sehingga keputusan untuk hari tersebut dapat disamakan.

Oleh karena hasil uji Kruskal-Wallis pada hari Senin, Kamis dan Sabtu adalah terdapat perbedaan jumlah penjualan, maka perlu untuk diketahui lebih lanjut apakah ada perbedaan jumlah penjualan untuk setiap hari senin setiap minggunya, hari Kamis setiap minggunya dan hari Sabtu setiap minggunya. Hasil pengujian Kruskal-Wallis dapat dilihat pada Tabel 3 dibawah ini

Tabel 3. Rekapitulasi hasil uji Kruskal-Wallis untuk tiap hari Senin, Kamis dan Sabtu setiap harinya untuk pedagang pertama

\begin{tabular}{|c|c|c|}
\hline Hari & P-Value & Kesimpulan \\
\hline Senin & 0.457 & Tidak menolak $\mathrm{H}_{0}$ \\
\hline Kamis & 0.462 & Tidak menolak $\mathrm{H}_{0}$ \\
\hline Sabtu & 0.462 & Tidak menolak $\mathrm{H}_{0}$ \\
\hline
\end{tabular}

Dari tabel 3 dapat dilihat bahwa dari kesimpulan uji Kruskal-Wallis didapatkan hasil tidak menolak $\mathrm{H}_{0}$ yang berarti tidak terdapat perbedaan jumlah penjualan per hari Senin, Kamis dan Sabtu setiap minggunya. Berdasarkan hasil dari seluruh uji Kruskal-Wallis yang dilakukan dapat diambil kesimpulan bahwa total keputusan mengenai jumlah dan jenis roti yang harus dibawa setiap harinya oleh kedua pedagang keliling roti berjumlah 8 keputusan. Hal ini berarti akan ada 8 keputusan yang berbeda-beda untuk kedua pedagang keliling berdasarkan hari apa mereka akan berjualan. Ke-8 keputusan itu dapat dilihat pada tabel 4 dibawah ini

Tabel 4. Rekapitulasi keputusan yang harus dibuat untuk kedua pedagang keliling toko roti $X$

\begin{tabular}{|l|l|}
\hline \multicolumn{2}{|c|}{ Pedagang } \\
\hline \multicolumn{1}{|c|}{ Pertama } & \multicolumn{1}{|c|}{ Kedua } \\
\hline 1. Jumlah dan jenis roti hari Senin & $\begin{array}{l}\text { 1. Jumlah dan jenis roti hari Senin, Kamis, dan } \\
\text { Sabtu }\end{array}$ \\
\hline 2. Jumlah dan jenis roti Selasa dan Rabu & 2. Jumlah dan jenis roti hari Selasa dan Rabu \\
\hline 3. Jumlah dan jenis roti Kamis & 3. Jumlah dan jenis roti hari Jumat \\
\hline 4. Jumlah dan jenis roti Jumat & \\
\hline 5. Jumlah dan jenis roti Sabtu & \\
\hline
\end{tabular}

Setelah didapatkan berapa banyak jumlah keputusan mengenai jumlah dan jenis roti yang harus dibawa setiap hari oleh kedua pedagang keliling roti $\mathrm{X}$, maka selanjutnya adalah mengimplementasikan program penyelesaian robust newsvendor problem untuk multi produk dan mempertimbangkan permintaan diskrit untuk mencari solusi pada tiap-tiap keputusan diatas yaitu berapa jumlah dan jenis roti yang akan dibawa setiap harinya. Solusi dari program penyelesaian model untuk pedagang keliling pertama dan pedagang keliling kedua dapat dilihat pada tabel 5 dan 6 dibawah ini 


\begin{tabular}{|c|c|c|c|c|c|c|c|c|c|}
\hline \multicolumn{10}{|c|}{ Pedagang keliling pertama } \\
\hline \multicolumn{2}{|c|}{ Senin } & \multicolumn{2}{|c|}{ Selasa dan Rabu } & \multicolumn{2}{|c|}{ Kamis } & \multicolumn{2}{|c|}{ Jumat } & \multicolumn{2}{|c|}{ Sabtu } \\
\hline Jenis roti & $q^{*}$ & Jenis roti & $\mathrm{q}^{*}$ & Jenis roti & $q^{*}$ & Jenis roti & $q^{*}$ & Jenis roti & $q^{*}$ \\
\hline 1 & 1.00501 & 1 & 1.003 & 1 & 1.001 & 1 & 2.4985 & 1 & 1.003 \\
\hline 2 & 2.00601 & 2 & 1.00701 & 2 & 1.00601 & 2 & 0 & 2 & 1.006 \\
\hline 3 & 2.5025 & 3 & 1.003 & 3 & 1.00501 & 3 & 2.00601 & 3 & 1.006 \\
\hline 4 & 1.003 & 4 & 1.001 & 4 & 1.001 & 4 & 1.001 & 4 & 1.002 \\
\hline 5 & 1 & 5 & 0 & 5 & 1 & 5 & 1 & 5 & 1.003 \\
\hline 6 & 0 & 6 & 1.002 & 6 & 1.001 & 6 & 0 & 6 & 1.001 \\
\hline 7 & 1.001 & 7 & 1.002 & 7 & 0 & 7 & 1.001 & 7 & 1.006 \\
\hline 8 & 1.001 & 8 & 1.001 & 8 & 1.001 & 8 & 1.001 & 8 & 1.003 \\
\hline 9 & 1.003 & 9 & 1.001 & 9 & 2 & 9 & 1.001 & 9 & 1.001 \\
\hline 10 & 1.003 & 10 & 1.003 & 10 & 1.003 & 10 & 1 & 10 & 1.003 \\
\hline 11 & 1.001 & 11 & 1.001 & 11 & 0 & 11 & 1.001 & 11 & 1.001 \\
\hline 12 & 1.001 & 12 & 1.003 & 12 & 1.001 & 12 & 0 & 12 & 1.001 \\
\hline 13 & 1.001 & 13 & 1.003 & 13 & 0 & 13 & 1.001 & 13 & 1.003 \\
\hline 14 & 1 & 14 & 1.003 & 14 & 1.003 & 14 & 1.003 & 14 & 1.003 \\
\hline 15 & 2 & 15 & 1.001 & 15 & 1.003 & 15 & 2 & 15 & 1.001 \\
\hline 16 & 1.003 & 16 & 1.001 & 16 & 2 & 16 & 0 & 16 & 1.998 \\
\hline 17 & 1.003 & 17 & 1 & 17 & 1 & 17 & 1 & 17 & 1 \\
\hline 18 & 1 & 18 & 0 & 18 & 0 & 18 & 1 & 18 & 1 \\
\hline 20 & 1 & 19 & 1 & 20 & 0 & 20 & 1 & 20 & 1 \\
\hline 21 & 1 & 20 & 1.001 & 21 & 1 & & & 21 & 1 \\
\hline & & 21 & 1 & & & & & & \\
\hline
\end{tabular}

Tabel 6. Solusi program penyelesaian model untuk pedagang keliling kedua

\begin{tabular}{|c|c|c|c|c|c|}
\hline \multicolumn{6}{|c|}{ Pedagang keliling kedua } \\
\hline \multicolumn{2}{|c|}{ Senin, Kamis, Sabtu } & \multicolumn{2}{|c|}{ Selasa dan Rabu } & \multicolumn{2}{|c|}{ Jumat } \\
\hline Jenis roti & $q^{*}$ & Jenis roti & $\mathrm{q}^{*}$ & Jenis roti & $\mathrm{q}^{*}$ \\
\hline 1 & 1.001 & 1 & 1.001 & 1 & 1.001 \\
\hline 2 & 0 & 2 & 0 & 2 & 5.00901 \\
\hline 3 & 2.002 & 3 & 2.002 & 3 & 2.002 \\
\hline 4 & 2.999 & 4 & 2.999 & 4 & 2.002 \\
\hline 5 & 1 & 5 & 1 & 5 & 1 \\
\hline 6 & 1.003 & 6 & 1.003 & 6 & 1.003 \\
\hline 7 & 0 & 7 & 0 & 7 & 0 \\
\hline 8 & 1.003 & 8 & 1.003 & 8 & 1.003 \\
\hline 9 & 1 & 9 & 1 & 9 & 1 \\
\hline 10 & 1 & 10 & 1 & 10 & 1 \\
\hline 11 & 1 & 11 & 1 & 11 & 1 \\
\hline 12 & 1 & 12 & 1 & 12 & 2 \\
\hline 13 & 2 & 13 & 1.003 & 13 & 2 \\
\hline 14 & 2 & 14 & 2 & 14 & 2 \\
\hline 15 & 1 & 15 & 1 & 15 & 1 \\
\hline 16 & 1 & 16 & 1 & 16 & 1 \\
\hline 17 & 1 & 17 & 1 & 17 & 1 \\
\hline 18 & 1 & 18 & 1 & 18 & 1 \\
\hline 20 & 1 & 19 & 1 & 20 & 1 \\
\hline
\end{tabular}




\begin{tabular}{|c|c|c|c|c|c|}
\hline \multicolumn{5}{|c|}{ Pedagang keliling kedua } \\
\hline Senin, Kamis, Sabtu & \multicolumn{2}{|c|}{ Selasa dan Rabu } & \multicolumn{2}{c|}{ Jumat } \\
\hline Jenis roti & $\mathrm{q}^{*}$ & Jenis roti & $\mathrm{q}^{*}$ & Jenis roti & $\mathrm{q}^{*}$ \\
\hline 21 & 1 & 20 & 1 & & \\
\hline & & 21 & 1 & & \\
\hline
\end{tabular}

Selanjutnya dilakukan perbandingan ekspektasi profit dari hasil robust newsvendor problem untuk multi produk dan mempertimbangkan permintaan diskrit dengan rata-rata profit per hari yang didapatkan oleh pedagang keliling berdasarkan keputusan saat ini yaitu berdasarkan pengalaman dari pemilik selama bulan Juli 2017 sampai dengan Januari 2018. Data perbandingan profit pedagang keliling pertama dan pedagang keliling kedua dapat dilihat pada tabel 7 dan 8 dibawah ini

Tabel 7. Perbandingan ekspektasi profit model usulan dengan rata-rata profit saat ini untuk pedagang keliling pertama

\begin{tabular}{|c|c|c|c|}
\hline \multicolumn{4}{|c|}{ Pedagang pertama } \\
\hline Hari & Rata-rata profit saat ini & Ekspektasi profit model usulan & Persentase profit \\
\hline Senin & Rp15,557.90 & Rp39,297.00 & $156,63 \%$ \\
\hline Selasa dan Rabu & Rp13,238.41 & Rp32,050.00 & $142,1 \%$ \\
\hline Kamis & Rp15,348.00 & Rp28,965.00 & $88,72 \%$ \\
\hline Jumat & Rp10,959.01 & Rp30,148.00 & $175,1 \%$ \\
\hline Sabtu & Rp20,400.00 & Rp35,780.00 & $75,4 \%$ \\
\hline
\end{tabular}

Tabel 8. Perbandingan ekspektasi profit model usulan dengan rata-rata profit saat ini untuk pedagang keliling kedua

\begin{tabular}{|c|c|c|c|}
\hline \multicolumn{3}{|c|}{ Pedagang kedua } \\
\hline Hari & Rata-rata profit saat ini & Ekspektasi profit model usulan & Persentase profit \\
\hline Senin, Kamis, Sabtu & Rp9,271.43 & Rp39,602.00 & $372,14 \%$ \\
\hline Selasa, Rabu & Rp12,703.92 & Rp38,750.00 & $205,02 \%$ \\
\hline Jumat & Rp13,118.18 & Rp48,935.00 & $273,03 \%$ \\
\hline
\end{tabular}

Berdasarkan tabel 7 dan 8 dapat dilihat bahwa ekspektasi profit tiap hari yang bisa didapatkan oleh kedua pedagang keliling dengan menggunakan robust newsvendor problem untuk multi produk dan mempertimbangkan permintaan diskrit lebih tinggi dari pada rata-rata profit kedua pedagang saat ini dengan menggunakan keputusan hanya berdasarkan perkiraan dan pengalaman dari pemilik.

\section{Simpulan}

Penelitian ini berhasil mengembangkan model robust newsvendor problem untuk multi produk dan mempertimbangkan permintaan diskrit untuk menyelesaikan permasalahan pada pedagang keliling. Model ini menentukan jumlah optimal yang harus dibawa oleh pedagang keliling setiap harinya untuk setiap jenis produk yang memaksimalkan ekspektasi profit dari kemungkinan terburuk yang dapat terjadi ketika hanya diketahui beberapa informasi dari distribusi permintaan.

Studi kasus pada penelitian ini adalah pedagang keliling suatu toko roti di Bandung. Hasil implementasi dari model yang sudah dikembangkan dapat meningkatkan rata-rata ekspektasi profit yang didapatkan oleh pedagang keliling pertama dan pedagang keliling kedua berturut-turut sebesar $126.77 \%$ dan $268.3987 \%$ dari rata-rata profit yang didapatkan oleh kedua pedagang keliling saat ini.

Saran untuk penelitian selanjutnya adalah membuat model robust newsvendor problem untuk multi produk dan mempertimbangkan permintaan diskrit dengan memperhatikan batasan kapasitas. Hal ini disebabkan karena pedagang keliling pada umumnya memiliki tempat untuk membawa barang dagangan yang terbatas. Selain itu dapat dilakukan perbaikan model yang dapat memberikan solusi akhir jumlah barang robust optimal yang harus dibawa oleh pedagang keliling juga bernilai diskrit, bukan kontinu.

\section{Ucapan Terima Kasih}

Penulis mengucapkan terimakasih kepada toko roti X yang mengizinkan kami melakukan penelitian di toko roti $\mathrm{X}$ dan boleh mengambil beberapa data yang kami perlukan untuk melakukan implementasi model robust newsvendor problem untuk multi produk dan mempertimbangkan permintaan diskrit pada kasus nyata. 


\section{Daftar Pustaka}

Choi, T-M. (2012). Handbook of Newsvendor Problem: Models, Extensions and Applications. International Series in Operations Research \& Management Science, Springer, New York.

Gallego, G. and Moon, I. (1993). The distribution free newsboy problem: review and extensions. Journal of the Operational Research Society, Vol 44(8), hal.825-834.

Qin, Y., Wang, R., Vakharia, A.J., Chen, Y., Seref, M.M.H. (2011). The Newsvendor Problem: Review and Directions for Future Research. European Journal of Operational Research, 213, hal.361-374.

Scarf, H. (1958). A min-max solution of an inventory problem. in Arrow, K., Karlin. S., and Scarf, H. Studies in The Mathematical Theory of Inventory and Production. Stanford University Press, California.

Turken, N., Tan, Y., Vakharia, A.J., Wang, L., Wang, R., Yenipazarli, A. (2012). The Multi-product Newsvendor Problem: Review, Ekstension, and Directions for Future Research. Handbook of Newsvendor Problem: Models, Extensions and Applications, Springer, New York.

Yu, H., Zhai, Jia., Sun, C. (2014). Robust Newsvendor Problem with Discrete Demand. 11th International Conference on Service System and Service Management (ICSSSM), IEEE, Beijing, China. 